\title{
Philippine Youth's Perceptions, Knowledge and Comprehension of Corruption in the Country
}

\author{
Raul A. Aquino ${ }^{1 *}$ \\ \{raul.aquino@lpu.edu.ph ${ }^{1}$ \} \\ Lyceum of the Philippines (LPU), Manila Campus, Muralla St, Intramuros, Manila, 1002 Metro \\ Manila, Philippines. ${ }^{1}$
}

\begin{abstract}
The moral education system can enable the younger generation to become responsible moral citizens in the future. An informed citizen who understands the moral importance in life will greatly help strengthen the democratic values of their country and reduce unethical behavior and corruption. Hence, this study determines the present perceptions, knowledge, and understanding of the Filipino youth on corruption in the country. This study utilized qualitative research approach to gather the primary data through questionnaire survey among the Filipino youth from sector of academic and police. The survey was participated by the Campus Integrity Crusades, Pamantasan ng Valenzuela, Office of the Ombudsman, Lyceum of the Philippines University, Manila, City of Malabon University, University of Caloocan, and Philippine National Police. The obtained qualitative data were analyzed through the content and textual analysis. The results obtained indicate that the respondents emphasized that corruption violates good behavior and has negative effects on society and country. The pervasiveness and extensiveness of corruption problem has led most people to believe that this is a norm in the country, with no response or resistance. The survey results also highlight that the current corruption situation in the Philippines is worrying.
\end{abstract}

Keywords: Philippine Youth; Corruption; Perceptions; Knowledge; Comprehension; Philippine.

\section{Introduction}

The United Nations described corruption as a complex social, political and economic phenomenon that affects all countries. Corruption undermines democratic institutions, slows economic development and contributes to governmental instability [1, 2]. It attacks the foundation of democratic institutions by distorting electoral processes, perverting the rule of law and creating bureaucratic quagmires whose only reason for existing is the soliciting of bribes. Economic development is stunted because foreign direct investment is discouraged and small businesses within the country often find it impossible to overcome the "start-up costs" required because of corruption.

Chugh [3] described corruption as a product of variety of actions or behaviors which make it very hard to establish a clear definition. Corruption is an inherently multi-level phenomenon. It can operate at individual, group, organization, and industry level. He defined corruption as a process which prevents the original nature of an individual or group from a purer state to a less pure state". He considered corruption as appropriate and what appropriate under the law and ethical and vice versa to standardize the motion of morality. 
El-Rayess[4], a faculty member in Columbian University, in her dissertation paper, investigated the students' behavior on corrupt practices acts in Bosnian public higher educational institutions using the Albert Hirschman's theory of voice, exit, and loyalty within higher education. Her findings revealed that the voice of Bosnian students supposedly as a powerful tool of the students in voicing out their concerns in educational issues affecting them become futile due to persisting systemic corruptions and fear from powerful faculty members who are not qualified but have strong influence in the corrupt environment. She also noted that students were dissatisfied the way their complaints were addressed due to lack of effective action.

Sika [5] found out that the Egyptian youth believed in democratic values but did not participate politically during the time of President Hosni Mubarak due to lack of understanding on the dynamics of authoritarian rule and corruption.

According toMansuri and Rao [6], corruption happens in some public sectors in India because of the general perception that a complaint creates a bad image on the institution; therefore it must be avoided or just simply ignores it. While there is a feedback mechanism design to address a certain complaint and improve the system, the said mechanism is not also responsive; thus, giving citizen participation to lose trust and confidence. He concluded therefore that the ability to address a certain complaint is a key factor in determining the kind of public perceptions on the issue of corruptions.

Transparency International Report 2013 [7] showed that the police (69\% of the respondents), public officials, and civil servants (64\% of the respondents) are perceived the most corrupt in the Philippines. In addition, Filipino respondents made the following perceptions in other institutions: Judiciary (56\%), Political Parties (55\%), legislatures (52\%), military (43\%), education and medical and health services (32\%), and media and religious $(15 \%)$.

Melgar, Rossi, and Smith [8] believed that the idea and understanding of corruption depends on the people and having a clear definition is a continuing challenge since the concept of corruption is influenced by society, culture, and country. For instance in Indonesia, the Supreme Court and Constitutional Court has a different interpretation of unlawful act of corruption which often lead to some Supreme Courts and prosecutors continue tocircumvent the Constitutional Court ruling [9]

Tavits[10] investigated the causes of corruption and focused her studies on the individual behavior and perceptions. She strongly believed that it is the people who are corrupt and not the country. She further added that corruption is more likely to happen if an individual is doing it voluntarily and not aware or no knowledge at all that what he/she is doing is morally or by situations it is wrong but believing it as an acceptable social behavior.

Heywood [11] posited that the level of corruption in an institution or organization is usually determined by the effectiveness of external auditing, level of administrative discipline, strength of internal policies and norms to preserve integrity and transparency, and the level of economic development. Therefore, this study aims to determine the Philippine youth's perceptions, knowledge and comprehension of corruption in the country. 


\section{Methodology}

The methodology of this study is a qualitative data analysis method that describes how Filipino youth aged 18-30 from the National Capital Region assesses and understands corruption in the Philippines.

\section{Research Design}

This study gathers the primary data through questionnaire survey from the selected organizations and institutions and the participants are age between 18 to 30 years old. There are 144 participants from six different organizations and institutions.

\section{Research Sample}

In the qualitative data analysis, a total of 144 respondents answered the interview guide questionnaires. Table 1 tabulates fifteen (15) Filipino youth respondents came from the Campus Integrity Crusades (CIC) in Pamantasan ng Valenzuela, forty-seven (47) employees from the Office of the Ombudsman, twelve (12) employees from the National Youth Commission (NYC), twenty (25) students from Taguig City University, twenty (26) students from the City of Malabon University, and nineteen (19) police personnel from the Philippine National Police (PNP).

Table 1. Respondents by Institution/Organization

\begin{tabular}{|l|l|l|}
\hline Organizations/Institutions & Frequency & Percent \\
\hline $\begin{array}{l}\text { Campus Integrity Crusades } \\
\text { (CIC) }\end{array}$ & 15 & 10.42 \\
\hline $\begin{array}{l}\text { City of Malabon University } \\
\text { (CMU) }\end{array}$ & 26 & 18.06 \\
\hline $\begin{array}{l}\text { National Youth Commission } \\
\text { (NYC) }\end{array}$ & 12 & 8.33 \\
\hline Office of the Ombudsman & 47 & 32.64 \\
\hline Philippine National Police (PNP) & 19 & 13.19 \\
\hline Taguig City University & 25 & 17.36 \\
\hline Total & $\mathbf{1 4 4}$ & $\mathbf{1 0 0 . 0 0}$ \\
\hline
\end{tabular}

\section{Research Instrument}

The research tool used in this study to gather the primary data is a designed survey questionnaire. The survey questionnaire was distributed to the participants to determine the Filipino youth's views, knowledge and understanding of corruption in the country. In addition, the survey questionnaire was validated by certified researchers in the Research and Innovation Center of the Lyceum of the Philippines University, Manila.

\section{Data Collection and Data Analysis}

The study was conducted from August 2017 to March 31, 2018 for approximately 8 months. This study includes survey and investigations that strictly adhere to all standard protocols during the investigation, especially in terms of ethics. Prior to the survey and investigation, the study was approved and supported by the appropriate organizations and institutions.

The questionnaires have been distributed to participants and assistance has been provided to better understand the survey questions. The obtained qualitative data were treated using the content and textual analysis.

Besides that, this study ensures that the identities of the participants are kept confidential, and the survey data obtained will be used only for the purposes of this study. 


\section{Result And Discussion}

This study used survey questionnaire to gather the primary data from 144 participants from six different organizations and institutions in order to determine the Philippine youth's perceptions, knowledge and comprehension of corruption in the country.

The views, knowledge and understanding of corruption among youth in the Philippines are:

Whether Corruption is a common practice in the Philippines

Table 2 presents the summary of the contents and context of the respondent's qualitative answers on whether corruption is a common practice in the Philippines. As seen above, 108 or $75 \%$ of the total 144 respondents said yes, corruption is a common practice in the country; 19 or $13.19 \%$ said no, it is not a common practice in the country; and the remaining 17 or $11.81 \%$ had no answer.

Accordingly, those respondents who said yes that corruption is a common practice in the Philippines, confirmed that corruption is common scenery, not lessening, and prevalent. They also observed that money is highly valued by many instead of honesty and integrity especially among politicians and high government officials.Palakasan and clannish culture are common which allow the propagation of corruption. On the other hand, thosewho answered no, that corruption is not a common practice in the country still believe that not all Filipinos are corrupt; that corruption is limited to some; and it was only perceptions that all Filipinos are corrupt. The respondent also believe that the present president is doing his best to solve and prevent corruption; that corruption is only done by selfish politicians and leaders who lack good values and manners; and blamed the past administration for its failure to address corruption; corruption is a personal choice and you cannot accused all of being corrupt; and no, it is not a common practice because many government agencies still preserve integrity and God-fearing.

Table 2. Summary of the Contents and Context of the Respondent's Qualitative answer on Whether Corruption is a common practice in the Philippines

\begin{tabular}{|l|l|l|l|l|l|}
\hline Answers & $\begin{array}{l}\text { Students, } \\
\text { NYC, \& } \\
\text { PNP }\end{array}$ & $\begin{array}{l}\text { Office of } \\
\text { the } \\
\text { Ombuds } \\
\text { man }\end{array}$ & $\begin{array}{l}\text { CI } \\
\text { C }\end{array}$ & $\begin{array}{l}\text { Tota } \\
\text { l }\end{array}$ & \% \\
\hline $\begin{array}{l}\text { Yes, it is a } \\
\text { common practice } \\
\text { in the country. }\end{array}$ & 67 & 26 & 15 & 108 & 75.00 \\
\hline $\begin{array}{l}\text { No, it is not a } \\
\text { common practice } \\
\text { in the country }\end{array}$ & 11 & 8 & 0 & 19 & 13.19 \\
\hline No Answer & 4 & 13 & 0 & 17 & 11.81 \\
\hline Total & $\mathbf{8 2}$ & $\mathbf{4 7}$ & $\mathbf{1 5}$ & $\mathbf{1 4 4}$ & $\mathbf{1 0 0 . 0 0}$ \\
\hline
\end{tabular}

Whether Corruption in the Philippines is an Acceptable Behavior

Table 3presents the summary of the contents and context of the respondent's qualitative answer on whether corruption is an acceptable behavior in the Philippines. As shown, 95 or $65.97 \%$ of the total respondents said no, corruption is not an acceptable behavior and 47 or 
$32.64 \%$ of the respondents said yes that corruption is now an acceptable behavior; and the remaining 2 or $1.39 \%$ had no answer.

For those who answers no, that corruption is not an acceptable behavior in the Philippines, some respondents provided the following explanation: they don't accept it as part of their moral principle; no but people are powerless to stop it because the leaders are the actors of corruption and tolerating it; no because they still believe that the President and some people are doing something to stop it; and no because there are people who has no knowledge that what they are doing is already an act of corruption. Two respondents from the Office of the Ombudsman tell that why people are very quiet and silent to discuss corruption because it is already a practiced and no one is interested to listen. Discussing the issue of corruption will only bring anxiety, fear, and hassle on your part.

Data implies that while it is true that corruption is a common knowledge and scenery in the country, it is not a generally accepted behavior. However, many of the respondents were convinced that majority of the Filipinos already accepted corruption as part of the cultural practices due to their passive and non-reactionary behaviors, concluding that it is a form of toleration. As said by former army Gen. Danilo Lim, "Dissent without action is consent". Also, the respondents have strongly observed that corruption is so widespread involving almost all institutions and sectors in society, particularly in the government wherein the actors and protectors of corruption are the most powerful, rich, and high officials of the country.

Corruption is a very sensitive issue to discuss in the workplace and in the community due to the present political environment of fear, lack of support and interest from the government, judicial system, and from the people itself, and the inconveniences that it will bring once you got involved and put interest into the issue.

Table 3. Summary of the Contents and Context of the Respondent's Qualitative answer on Whether Corruption in the Philippines is an Acceptable Behavior

\begin{tabular}{|c|c|c|c|c|c|}
\hline Answers & $\begin{array}{l}\text { Students, } \\
\text { NYC, \& } \\
\text { PNP }\end{array}$ & $\begin{array}{l}\text { Office of } \\
\text { the } \\
\text { Ombuds } \\
\text { man }\end{array}$ & $\begin{array}{l}\text { CI } \\
\text { C }\end{array}$ & $\begin{array}{l}\text { Tot } \\
\text { al }\end{array}$ & $\%$ \\
\hline $\begin{array}{l}\text { No, it is not an } \\
\text { acceptable } \\
\text { behavior in the } \\
\text { Philippines }\end{array}$ & 58 & 31 & 6 & 95 & 65.97 \\
\hline $\begin{array}{l}\text { Yes, corruption is } \\
\text { now an } \\
\text { acceptable } \\
\text { behavior in the } \\
\text { Philippines }\end{array}$ & 24 & 14 & 9 & 47 & 32.64 \\
\hline No Answer & 0 & 2 & 0 & 2 & 1.39 \\
\hline Total & 82 & 47 & 15 & 144 & 100.00 \\
\hline
\end{tabular}

The definition, description, or understanding of corruption

Table 4 presents the summary of the contents and context of the respondent's qualitative answer on what is your definition, description, or understanding of corruption. In the analysis of qualitative data about how the Filipino youth defined, described, and understand the word "corruption", 44 or $30.56 \%$ of the 144 respondents opined that corruption is any act that is unethical, evil, illegal, and harmful that destroys integrity [12]. Common examples are 
cheating, lying, abuse or misuse of power from person in authority for personal gain (26.39 $\%)$, it is about stealing of money because people believe that money is power $(22.92 \%)$, it's about selfishness or greediness $(8.33 \%) ; 6.25 \%$ of the respondents believe that corruption is harmful to society; two (2) or $1.39 \%$ of the respondents thinks that it is a crime; and six (6) or $4.16 \%$ have no answer.

Table4. Summary of the Contents and Context of the Respondent's Qualitative answer on What is your definition, description, or understanding of corruption

\begin{tabular}{|l|l|l|l|l|l|}
\hline Answers & $\begin{array}{l}\text { NYC, } \\
\text { Student } \\
\text { s, PNP }\end{array}$ & $\begin{array}{l}\text { Office } \\
\text { of the } \\
\text { Ombud } \\
\text { sman }\end{array}$ & $\begin{array}{l}\text { CI } \\
\text { C }\end{array}$ & $\begin{array}{l}\text { Tot } \\
\text { al }\end{array}$ & $\mathbf{\%}$ \\
\hline Stealing & 28 & 4 & 1 & 33 & 22.92 \\
\hline $\begin{array}{l}\text { Illegal } \\
\text { behavior of } \\
\text { people }\end{array}$ & 18 & 17 & 9 & 44 & 30.56 \\
\hline $\begin{array}{l}\text { Misuse of } \\
\text { power }\end{array}$ & 16 & 18 & 4 & 38 & 26.39 \\
\hline Greediness and & 8 & 4 & 0 & 12 & 8.33 \\
\hline $\begin{array}{l}\text { Harmful and } \\
\text { dangerous to } \\
\text { society }\end{array}$ & 5 & 3 & 1 & 9 & 6.25 \\
\hline Crime & 2 & 0 & 0 & 2 & 1.39 \\
\hline No answer & 5 & 1 & 0 & 6 & 4.16 \\
\hline Total & $\mathbf{8 2}$ & $\mathbf{4 7}$ & $\mathbf{1 5}$ & $\mathbf{1 4 4}$ & $\mathbf{1 0 0 . 0 0}$ \\
\hline
\end{tabular}

Corruption is persistent in the Philippines despite the consequences and penalty

Table 5 presents the summary of the respondent's qualitative answers on why corruption persists despite its consequences and penalty. As revealed, 40 or $27.28 \%$ believed it is because of bad leadership and governance serving as the orchestrator and protector; $14.58 \%$ claims for non-contentment in life, greediness/love of money; $11.81 \%$ because of the poor laws and justice system; $5.56 \%$ said it has become a culture; 2 or $1.39 \%$ said because of poverty and lack of education; 1 or .69\% said because of low salary; 3 or $2.08 \%$ answered others; and 48 or $35.22 \%$ did not answer.

The data suggest that bad leadership and governance is the main cause why corruption persist and rampant in the country. These bad leaders were effective in creating an environment of fear that conditions the minds of the Filipinos to become submissive, cooperative, and accept corruption as a process or culture in the country [13].

Table5. Summary of the Contents and Context of the Qualitative answers of the Filipino Youth Respondent's Qualitative answer on Why Corruption is persistent in the Philippines despite the consequences and penalty

\begin{tabular}{|l|l|l|l|l|l|}
\hline Reasons & $\begin{array}{l}\text { Students } \\
\text { NYC, } \\
\text { \& PNP }\end{array}$ & $\begin{array}{l}\text { Office of } \\
\text { the } \\
\text { Ombuds } \\
\text { man }\end{array}$ & $\begin{array}{l}\text { CI } \\
\text { C }\end{array}$ & $\begin{array}{l}\text { Tot } \\
\text { al }\end{array}$ & $\%$ \\
\hline $\begin{array}{l}\text { Bad leadership } \\
\text { and governance }\end{array}$ & 27 & 3 & 5 & 40 & 27.28 \\
\hline
\end{tabular}




\begin{tabular}{|l|l|l|l|l|l|}
\hline $\begin{array}{l}\text { Non } \\
\text { contentment in } \\
\text { life, } \\
\text { greediness/love } \\
\text { of money }\end{array}$ & 15 & 1 & 5 & 21 & 14.58 \\
\hline $\begin{array}{l}\text { Poor laws and } \\
\text { justice }\end{array}$ & 10 & 3 & 4 & 17 & 11.81 \\
\hline Culture & 8 & 0 & 0 & 8 & 5.56 \\
\hline Poverty of & 2 & 0 & 0 & 2 & 1.39 \\
\hline $\begin{array}{l}\text { Lack } \\
\text { education }\end{array}$ & 1 & 1 & 0 & 2 & 1.39 \\
\hline Low salary & 0 & 0 & 1 & 1 & .69 \\
\hline Others & 3 & 0 & 0 & 3 & 2.08 \\
\hline No answer & 9 & 39 & 0 & 48 & 35.22 \\
\hline Total & $\mathbf{8 2}$ & $\mathbf{4 7}$ & $\mathbf{1 5}$ & $\mathbf{1 4 4}$ & $\mathbf{1 0 0 . 0 0}$ \\
\hline
\end{tabular}

The motivates of a person to do corruption

The result in Table 6 shows that love of money, power, prestige, and non-contentment in life leading to selfishness and greediness are the main reasons why a person is motivated to do corruption with $39.58 \%$. Other reasons cited were poverty $13.89 \%$; environmental influence in the workplace and community $5.56 \%$; personal needs $4.17 \%$; culture and weak value system of the person $3.47 \%$; other comments $2.77 \%$ and $30.56 \%$ of the total 144 respondents did not give any answer.

Looking at both results, it shows that money and power are the main reasons why a person/s are magnetized to commit corruption. Respondents also identified that those people involve are rich and have positions in government and in society who use their power and influence to dictate the tempo and create an atmosphere of fear and intimidation to others, forcing them to cooperate and not to question, and/ or to remain silent about corruption issues.

Table 6. Summary of the Contents and Context of the Respondent's Qualitative answer on

What motivates a person/s to do corruption?

\begin{tabular}{|c|c|c|c|c|c|}
\hline $\begin{array}{l}\text { What } \\
\text { motivates a } \\
\text { person to do } \\
\text { corruption? }\end{array}$ & $\begin{array}{l}\text { NYC, } \\
\text { Student } \\
\text { s, PNP }\end{array}$ & $\begin{array}{l}\text { Office } \\
\text { of the } \\
\text { Ombud } \\
\text { sman }\end{array}$ & $\begin{array}{l}\text { CI } \\
\mathbf{C}\end{array}$ & $\begin{array}{l}\text { Tot } \\
\text { al }\end{array}$ & $\%$ \\
\hline $\begin{array}{l}\text { Greediness due } \\
\text { to love money, } \\
\text { power, } \\
\text { prestige, non- } \\
\text { contentment in } \\
\text { life }\end{array}$ & 50 & 5 & 2 & 57 & 39.58 \\
\hline Poverty & 14 & 1 & 5 & 20 & 13.89 \\
\hline $\begin{array}{lr}\begin{array}{l}\text { Culture } \\
\text { weak }\end{array} & \text { and } \\
\text { system } & \text { value } \\
\end{array}$ & 4 & 0 & 1 & 5 & 3.47 \\
\hline Personal needs & 4 & 1 & 1 & 6 & 4.17 \\
\hline $\begin{array}{l}\text { Environmental } \\
\text { influence }\end{array}$ & 2 & 0 & 6 & 8 & 5.56 \\
\hline
\end{tabular}




\begin{tabular}{|l|l|l|l|l|l|}
\hline Comments & 3 & 1 & 0 & 4 & 2.77 \\
\hline No answer & 5 & 39 & 0 & 44 & 30.56 \\
\hline Total & $\mathbf{8 2}$ & $\mathbf{4 7}$ & $\mathbf{1 5}$ & $\mathbf{1 4 4}$ & $\mathbf{1 0 0 . 0 0}$ \\
\hline
\end{tabular}

People who are primarily involved in abuse and corruption

Table 7 demonstrates the summary of the contents and context of the respondent's qualitative answer on people mostly involved in corruption and abuses. As regard to who are the people mostly involved in corruption and abuses, the politicians ranked number one which was identified 80 times; followed by the government employees mentioned 45 times; next were the police which was mentioned 44 times; then government officials mentioned 36 times; businessmen mentioned 22 times; and lastly the education sector which was mentioned 17 times.

Table7. Summary of the Contents and Context of the Respondent's Qualitative answer on people mostly involved in corruption and abuses

\begin{tabular}{|l|l|l|l|l|}
\hline $\begin{array}{l}\text { Mostly } \\
\text { involved in } \\
\text { Corruption }\end{array}$ & $\begin{array}{l}\text { NYC, } \\
\text { Students, } \\
\text { \& PNP }\end{array}$ & $\begin{array}{l}\text { Office of the } \\
\text { Ombudsman }\end{array}$ & CIC & $\begin{array}{l}\text { Total } \\
\text { mentioned }\end{array}$ \\
\hline Politicians & 43 & 25 & 12 & 80 \\
\hline $\begin{array}{l}\text { Government } \\
\text { employees }\end{array}$ & 16 & 17 & 12 & 45 \\
\hline Police & 12 & 25 & 7 & 44 \\
\hline $\begin{array}{l}\text { Government } \\
\text { officials }\end{array}$ & 16 & 17 & 12 & 36 \\
\hline Businessmen & 18 & 3 & 1 & 22 \\
\hline Education & 13 & 3 & 1 & 17 \\
\hline
\end{tabular}

Institutions/Sectors who are primarily involved in abuse and corruption

Table 8 illustrates the list of institutions/sectors considered as the most corrupt in the country by the respondents. Ranked from highest to lowest, Bureau of Custom is on top of the list with a total of 73 mentioning from the different group of respondents. It is followed by the BIR with 52; PNP with 40; DPWH with 38; LGU and LTO with 37 each respectively; then Congress with 33; and Education with 29. The results explain that corruption is so widespread in the Philippines whether in government or in private sectors.

As observed by Hutchcroft[14], "There is collusion among public and private enterprises in the Philippines resulting to the weakening of state institutions to perform its mandate honestly and justly".

Table8. Summary of the Contents of the Respondent's Answer whom they considered as the most Corrupt Institutions/Sectors in the Philippines

\begin{tabular}{|l|l|l|l|l|}
\hline Institutions & $\begin{array}{l}\text { NYC, } \\
\text { Students, \& } \\
\text { PNP }\end{array}$ & $\begin{array}{l}\text { Office of the } \\
\text { Ombudsman }\end{array}$ & CIC & $\begin{array}{l}\text { Total } \\
\text { mentioned }\end{array}$ \\
\hline $\begin{array}{l}\text { Bureau of } \\
\text { Customs }\end{array}$ & 31 & 28 & 14 & 73 \\
\hline BIR & 21 & 20 & 11 & 52 \\
\hline PNP & 11 & 17 & 12 & 40 \\
\hline DPWH & 12 & 20 & 6 & 38 \\
\hline LGU & 17 & 15 & 5 & 37 \\
\hline
\end{tabular}




\begin{tabular}{|l|l|l|l|l|}
\hline LTO & 10 & 19 & 8 & 37 \\
\hline Congress & 15 & 11 & 7 & 33 \\
\hline Education & 22 & 7 & 0 & 29 \\
\hline
\end{tabular}

Reasons why people are not reporting wrongdoings/corruption acts

Based on Table 9, people are very hesitant or not filing a complaint against corruption and wrongdoings in the country because of fear with 57 or $39.58 \%$ due to possible retaliation. 23 or $15.97 \%$ noted that many Filipinos are not interested party against corruption on the belief that the government will not give them the necessary support and protection with 8 or $5.56 \%$. However, it was noted that 56 or 38.89 of the respondents did not answer nor give any comment on this question.

Table9. Summary of the Contents and Context of the Qualitative answers of the Filipino Youth Respondents why people are hesitant or not filing a complaint against wrongdoings or corruption acts

\begin{tabular}{|l|l|l|l|l|l|}
\hline $\begin{array}{l}\text { Reasons why } \\
\text { people are not } \\
\text { reporting } \\
\text { wrongdoings/ } \\
\text { corruption } \\
\text { acts }\end{array}$ & $\begin{array}{l}\text { NYC, } \\
\text { Student } \\
\text { s, \& } \\
\text { PNP }\end{array}$ & $\begin{array}{l}\text { Office } \\
\text { of the } \\
\text { Ombud } \\
\text { sman }\end{array}$ & $\begin{array}{l}\text { CI } \\
\text { C }\end{array}$ & $\begin{array}{l}\text { Tot } \\
\text { al }\end{array}$ & $\mathbf{\%}$ \\
\hline Fear & 47 & 2 & 8 & 57 & 39.58 \\
\hline Not interested & 20 & 0 & 3 & 23 & 15.97 \\
\hline $\begin{array}{l}\text { Lack of Trust } \\
\text { to the } \\
\text { Government }\end{array}$ & 4 & 0 & 4 & 8 & 5.56 \\
\hline No answer & 11 & 45 & 0 & 56 & 38.89 \\
\hline Total & $\mathbf{8 2}$ & $\mathbf{4 7}$ & $\mathbf{1 5}$ & $\mathbf{1 4 4}$ & $\mathbf{1 0 0 . 0 0}$ \\
\hline
\end{tabular}

The Culture of Vindictiveness of Filipinos

Table 10 presents the summary of the contents and context of the respondent's qualitative answers on the culture of vindictiveness of Filipinos. As seen, 59 or $40.97 \%$ of the respondents answered yes, I do believe that Filipinos are vindictive in nature; 5 or $3.47 \%$ answered no, I don't believe Filipinos are vindictive in nature; 77 or the highest percentage of 53.47 did not any indicate answer; 1 or $.69 \%$ said that there is a chance to take revenge; and the remaining 2 or 1.40 said they don't know.

Table10. Summary of the Contents and Context of the Respondent's Qualitative answers on the Culture of Vindictiveness of Filipinos

\begin{tabular}{|l|l|l|l|l|l|l|}
\hline Answers & \multicolumn{2}{|l|}{$\begin{array}{l}\text { Student } \\
\text { s, NYC, } \\
\text { \& PNP }\end{array}$} & $\begin{array}{l}\text { Office } \\
\text { of the } \\
\text { Ombud } \\
\text { sman }\end{array}$ & $\begin{array}{l}\text { CI } \\
\text { Con }\end{array}$ & $\begin{array}{l}\text { Tot } \\
\text { al }\end{array}$ & \% \\
\hline $\begin{array}{l}\text { Yes, I do } \\
\text { believe } \begin{array}{r}\text { that } \\
\text { Filipinos are } \\
\text { vindictive in } \\
\text { nature }\end{array}\end{array}$ & & 1 & 13 & 59 & 40.97 \\
\hline $\begin{array}{l}\text { No, I don't } \\
\text { believe }\end{array}$ & 4 & 0 & 1 & 5 & 3.47 \\
\hline
\end{tabular}




\begin{tabular}{|l|l|l|l|l|l|}
\hline $\begin{array}{l}\text { Filipinos are } \\
\text { vindictive in } \\
\text { nature }\end{array}$ & & & & & \\
\hline No Answer & 32 & 46 & 0 & 77 & 53.47 \\
\hline $\begin{array}{l}\text { There is a } \\
\text { chance to take } \\
\text { revenge }\end{array}$ & 1 & 0 & 0 & 1 & .69 \\
\hline Don't know & 1 & 0 & 1 & 2 & 1.40 \\
\hline Total & $\mathbf{8 2}$ & $\mathbf{4 7}$ & $\mathbf{1 5}$ & $\mathbf{1 4 4}$ & $\mathbf{1 0 0 . 0 0}$ \\
\hline
\end{tabular}

Consequences of complainant / whistleblower corruption or any misconduct

Table 11 demonstrates what usually happens to the complainant or whistleblower of corruption and wrongdoings. Respondents said that they are threatened/intimidate/isolated which was mentioned 51 times equivalent to $35.42 \%$; complainant get killed mentioned 9 times or $6.25 \%$; supported and protected with 8 or $5.56 \%$; bribed with 6 or $4.17 \%$; other answers with 8 or $5.56 \%$; and no answer dominated with 62 or $43.04 \%$.

Majority of the respondents from National Youth Commission, Philippine National, Police and students who answered the interview guide questionnaire were strongly convinced that complaint against corruption and wrongdoings usually failed, rejected, or end to nothing due to long processes, biases, threats, and other forms of intimidation against the complainant, giving the latter no other choice but to withdraw, not to file a case anymore, to keep quiet, or have opted to accept payment in exchange of personal benefits, safety, and peacefulness.

In addition, most of the qualitative respondents strongly believed that the complainant/s on corruption are usually killed, suffers tremendous fear, psychological, and emotional pain due to all forms of harassment and intimidation such as threat to his life, family and relatives, work isolation, and counter false charges forcing the complainant to withdraw the complaint. Others opted to accept bribe in exchange of safety, silence, and benefits. Only few complainants get full support and protection once they filed the case.

All these instances or situations are highly visible in Philippine setting knowing our culture of close-knitted relationship, palakasan system, culture of impunity, tolerance, culture of vindictiveness and fear, inconsistent and complicated policies, weak and dysfunctional government institutions that failed to provide the necessary support and protection to the whistleblowers or complainant resulting to withdrawal, rejection or dismissal of cases.

With these data and information, it can be deduced that pursuing to go against corruption in the country is very dangerous and difficult due to strong political environment, tedious and toxic legal processes forcing the complainant to withdraw, to cooperate with the corrupt, or to think many times before deciding to file a complaint.

Table 11. Summary of contents and context of the Respondent's Qualitative answers on what usually happens to the complainant/whistleblower of corruption or any wrongdoings

\begin{tabular}{|l|l|l|l|l|l|}
\hline $\begin{array}{l}\text { What Usually } \\
\text { happened to } \\
\text { the } \\
\text { complainant? }\end{array}$ & $\begin{array}{l}\text { NYC, } \\
\text { Student } \\
\text { s, \& } \\
\text { PNP }\end{array}$ & $\begin{array}{l}\text { Office } \\
\text { of the } \\
\text { Ombud } \\
\text { sman }\end{array}$ & $\begin{array}{l}\text { CI } \\
\text { Con }\end{array}$ & $\begin{array}{l}\text { Tot } \\
\text { al }\end{array}$ & \% \\
\hline $\begin{array}{l}\text { Threatened/Inti } \\
\text { midated/isolate } \\
\text { d }\end{array}$ & 39 & 2 & 10 & 51 & 35.42 \\
\hline $\begin{array}{l}\text { Complainant } \\
\text { Get killed }\end{array}$ & 9 & 0 & 0 & 9 & 6.25 \\
\hline
\end{tabular}




\begin{tabular}{|l|l|l|l|l|l|}
\hline $\begin{array}{l}\text { Supported and } \\
\text { Protected }\end{array}$ & 3 & 0 & 5 & 8 & 5.56 \\
\hline Bribed & 6 & 0 & 0 & 6 & 4.17 \\
\hline Other answers & 8 & 0 & 0 & 8 & 5.56 \\
\hline No answer & 17 & 45 & 0 & 62 & 43.04 \\
\hline Total & $\mathbf{8 2}$ & $\mathbf{4 7}$ & $\mathbf{1 5}$ & $\mathbf{1 4 4}$ & $\mathbf{1 0 0 . 0 0}$ \\
\hline
\end{tabular}

Consequences of a reported corruption complaint

Table 12 presents the summary of the contents and context of the respondents answer on what usually happens to the reported complaints about corruption. As seen, 72 or $50 \%$ of the total respondents said that the complaint undergoes a very tedious process ending to nothing; 13 or $9.03 \%$ said that complaint is automatically rejected and ignored; 12 or $8.33 \%$ said it is accepted, investigated with optimism to prosper; and the rest which is 47 or $32.64 \%$ had no answer. The analyses suggest that getting real and truthful justice system in the Philippines is very difficult and an elusive dream for many.

As pointed out by legal luminaries and by the Filipino people, Philippine justice system is such problematic that it cannot be trusted especially for those who are victims, oppressed, and in less in life.

Table 12. Summary of the Contents \& Context of the Respondent's Qualitative answer on the question What usually happens to the reported complaints on corruption

\begin{tabular}{|l|l|l|l|l|l|}
\hline $\begin{array}{l}\text { What usually } \\
\text { happened to } \\
\text { the } \\
\text { complaints on } \\
\text { corruption } \\
\text { and } \\
\text { wrongdoings? }\end{array}$ & $\begin{array}{l}\text { NYC, } \\
\text { Student } \\
\text { s\& PNP }\end{array}$ & $\begin{array}{l}\text { Office } \\
\text { of the } \\
\text { Ombud } \\
\text { sman }\end{array}$ & $\begin{array}{l}\text { CI } \\
\text { Con }\end{array}$ & $\begin{array}{l}\text { Tot } \\
\text { al }\end{array}$ & \\
\hline $\begin{array}{l}\text { Undergoes a } \\
\text { tedious process } \\
\text { ending to } \\
\text { nothing }\end{array}$ & 59 & 2 & 11 & 72 & 50.00 \\
\hline $\begin{array}{l}\text { Automatically } \\
\text { rejected and } \\
\text { ignored }\end{array}$ & 13 & & 0 & 13 & 9.03 \\
\hline $\begin{array}{l}\text { Accepted, } \\
\text { investigated } \\
\text { with optimism } \\
\text { to prosper }\end{array}$ & 8 & 0 & 4 & 12 & 8.33 \\
\hline No answer & 2 & 45 & 0 & 47 & 32.64 \\
\hline Total & $\mathbf{8 2}$ & $\mathbf{4 7}$ & $\mathbf{1 5}$ & $\mathbf{1 4 4}$ & $\mathbf{1 0 0 . 0 0}$ \\
\hline
\end{tabular}

Filipino behavior and response and its role in preventing corruption

Table 13 shows the summary of the contents and context of the Filipino behaviors and reactions and its effects in preventing corruption. As revealed, 67 or $46.53 \%$ answered no, the present reactions and behaviors of the Filipinos against corruption seems to have no effect at all; 66 or $45.83 \%$ answered yes, the present reaction and behaviors of the Filipinos show positive effect in preventing corruption; 2 or $1.39 \%$ with mixed answer; and 9 or $6.25 \%$ with no answer at all. 
Table 13. Summary of the Contents and Context of Respondent's Qualitative answers on Filipino Behaviors and Reactions and its Effect of Preventing Corruptions

\begin{tabular}{|l|l|l|l|l|l|}
\hline $\begin{array}{l}\text { Present } \\
\text { reactions and } \\
\text { behaviors of } \\
\begin{array}{l}\text { Filipino and its } \\
\text { Effect in } \\
\text { Preventing } \\
\text { Corruption }\end{array}\end{array}$ & $\begin{array}{l}\text { NYC, } \\
\text { Student } \\
\text { and }\end{array}$ & $\begin{array}{l}\text { Office } \\
\text { of the } \\
\text { Ombu } \\
\text { dsman }\end{array}$ & $\begin{array}{l}\text { CI } \\
\text { CNP }\end{array}$ & $\begin{array}{l}\text { Tot } \\
\text { al }\end{array}$ & \% \\
\hline $\begin{array}{l}\text { No, the present } \\
\text { reactions and } \\
\text { behaviors of the } \\
\text { Filipinos against } \\
\text { corruption seem } \\
\text { to have no } \\
\text { effect at all. }\end{array}$ & 37 & 21 & 9 & 67 & 46.53 \\
\hline $\begin{array}{l}\text { Yes, the present } \\
\text { reactions and } \\
\text { behaviors of the } \\
\text { Filipinos against } \\
\text { corruption show } \\
\text { positive effect. }\end{array}$ & 39 & 21 & 6 & 66 & 45.83 \\
\hline Mixed Answers & 0 & 2 & 0 & 2 & 1.39 \\
\hline No Answer & 6 & 3 & 0 & 9 & 6.25 \\
\hline Total & $\mathbf{8 2}$ & $\mathbf{4 7}$ & $\mathbf{1 5}$ & $\mathbf{1 4 4}$ & $\mathbf{1 0 0 . 0 0}$ \\
\hline
\end{tabular}

Current corruption status in the Philippines

Table 14 presents the summary of contents and context of the present corruption situation as described by the Filipino youth. Out of the total 144 respondents, 124 or $86.11 \%$ described it as worst and the remaining 20 or $13.89 \%$ described it as improved.

Table 14. Summary of Contents and Context of the Respondent's Qualitative answers on Present Corruption Situation of the Philippines

\begin{tabular}{|l|l|l|l|l|l|}
\hline $\begin{array}{l}\text { Corruptio } \\
\text { n Situation }\end{array}$ & $\begin{array}{l}\text { NYC, } \\
\text { Students, } \\
\text { and PNP }\end{array}$ & $\begin{array}{l}\text { Ombu } \\
\text { dsman }\end{array}$ & CIC & $\begin{array}{l}\text { Tot } \\
\text { al }\end{array}$ & $\mathbf{\%}$ \\
\hline Worst & 70 & 41 & 13 & 124 & 86.11 \\
\hline Improved & 4 & 4 & 12 & 20 & 13.89 \\
\hline Total & $\mathbf{8 2}$ & $\mathbf{4 7}$ & $\mathbf{1 5}$ & $\mathbf{1 4 4}$ & $\mathbf{1 0 0 . 0 0}$ \\
\hline
\end{tabular}

Because of the qualitative disappointing assessment on the present corruption situation of the country, it can be said that the present corruption situation of the country did not improve and even worsen due to weak reactions of the Filipino people to go against corruption encouraging some Filipino youth respondents to suggest a more radical solution by saying to kill them all or imposed death penalty for corrupt officials. Other respondents encouraged to impose and practice integrity and honesty, particularly on powerful people, have the political will and be more concern with the poor and country, all aspiring government officials must undergo strict background check and to put limits on their power, and increase the penalty on corruption with strict implementation of the law. 


\section{Conclusion}

In conclusion, the obtained result from the survey indicated majority of the participants agree that corruption is a common practice in the country. Next, majority of the respondents claim that corruption is not an acceptable behavior.Most of the Filipino youth defined, described, and understand the word "corruption", is any act that is unethical, evil, illegal, and harmful that destroys integrity

Besides that, many respondents knowing that corruption is persistent in the Philippines despite the consequences and penaltybecause of bad leadership and governance serving as the orchestrator and protector as well as the non-contentment in life, greediness and love of money. The obtained survey result also indicates that love of money, power, prestige, and non-contentment in life leading to selfishness and greediness are the main reasons why a person is motivated to do corruption.

As regard to who are the people mostly involved in corruption and abuses, the politicians ranked number one followed by the government employees. Correspondingly, Bureau of Custom is on top of the list of institutions/sectors considered as the most corrupt in the country by the respondents

People are very hesitant or do not complain about corruption and wrongdoing in the country because of fear of possible retaliation. Also, majority of the respondents do believe that Filipinos are vindictive in nature. Most respondent claims they will be threatened, intimidate, and isolated to the complainant or whistleblower of corruption and wrongdoings. In addition, most respondents believe that the complaint undergoes a very tedious process ending to nothing.

About half of the respondents the present reactions and behaviors of the Filipinos against corruption seems to have no effect at all, while the remaining half of the respondents agree that the present reaction and behaviors of the Filipinos show positive effect in preventing corruption.Lastly, most respondents agree that of the present corruption situation in the country is worst.

\section{ACKNOWLEDGMENTS}

The authors would like to thank the participants and unconditional support from the Research and Innovation Center, Lyceum of the Philippines University.

\section{References}

[1] Corruption undermines democracy and contributes to instability, warns senior UN anti-crime official. 2019. [Internet]. United Nations News. [Cited 2 April 2020]. Available from: https://news.un.org/en/story/2019/08/1045081

[2] International Anti-Corruption Day 9 December. [Internet]. United Nations. [Cited 2 April 2020]. Available from: https://www.un.org/en/observances/anti-corruption-day/background

[3] Chugh, D. 2012. Psychology of Corruption. Journal: The Learning Curve, Lady Shri Ram College for Women Finalist, Young Psychologist 2012. [Internet]. [Cited 2 April 2020]. Available from: https://ssrn.com/abstract $=2117247$

[4] Sabic-El-Rayess, A. 2014. Acting and Reacting: Youth's Behavior in Corrupt Educational Settings. Peabody Journal of Education. 89. 70-85. DOI=10.1080/0161956X.2014.862473. 
[5] Sika, N. 2012. Youth Political Engagement in Egypt. From Abstention to Uprising. [Internet]. [Cited 2 April 2020]. Available from: https://www.tandfonline.com/doi/abs/10.1080/13530194.2012.709700 on March 17, 2019

[6] Mansuri, G.; Rao, V. Localizing Development: Does Participation Work? Washington, DC: World Bank. 2013.

[7] Transparency International Report 2013. [Internet]. Transparency International. [Cited 2 April 2020]. Available from: https://www.transparency.org/gcb2013/country?country=philippines

[8] Melgar, N., Rossi, M. and Smith, T.W. 2010. The perception of corruption. International Journal of Public Opinion Research. 22, 1, 120-31.

[9] Wibowo, R. A. 2018. When anti-corruption norms lead to undesirable results: learning from the Indonesian experience. Crime, Law and Social Change, 70(3), 383-396.

[10] Tavits, M. 2005. Causes of Corruption: Testing Competing Hypotheses. Nuffield College, University of Oxford [Internet]. [Cited 2 April 2020]. Available from: http://www.nuffield.ox.ac.uk/politics/papers/2005/Tavits\%20Nuffield\%20WP.pdf on January 29,2016

[11] Heywood, A. 2007. Politics 3rd Edition. Palgrave Macmillan. 175 Fifth Avenue, New York, NY 10010, USA

[12] Graaf, G. D., and Huberts, L. 2018. Integrity Violations and Corruption in Western Public Administration: Empirical Evidence and Reflection from Netherlands. Public Integrity, American Society of Public Administration, Washington DC, USA. 131-149.

[13] Keegan, S. M.2015. The Psychology of Fear in Organizations, Kogan Page Limited, Great Britain and United States of America.

[14] Hutchcroft, P. D. 1998. Booty Capitalism: The Politics of Banking in the Philippines. Ithaca: Cornell University Press 